\title{
Molecular Dynamics Study of the Effect of Carbon Atoms on the Surface Tension of Silicon-carbon Alloy
}

\author{
Taka NARUMI, ${ }^{1) *}$ Yasushi SHIBUTA ${ }^{2)}$ and Takeshi YOSHIKAWA ${ }^{3)}$ \\ 1) Institute of Industrial Science, The University of Tokyo. Now at Department of Materials Science and Engineering, Kyoto \\ University, Yoshida-honmachi, Sakyo-ku, Kyoto, Kyoto, 606-8501 Japan. \\ 2) Department of Materials Engineering, The University of Tokyo, 7-3-1 Hongo, Bunkyo-ku, Tokyo, $113-8656$ Japan. \\ 3) Institute of Industrial Science, The University of Tokyo, 4-6-1 Komaba, Meguro-ku, Tokyo, 153-8505 Japan.
}

(Received on May 18, 2019; accepted on August 16, 2019; J-STAGE Advance published date:

October 14, 2019)

\begin{abstract}
We conducted molecular dynamics simulations of $\mathrm{Si}-\mathrm{C}$ alloy to understand the atomistic behavior of solute $\mathrm{C}$ atoms near the melt surface and to estimate the surface tension. The surface tensions of liquid $\mathrm{Si}$ and $\mathrm{C}$ were first evaluated and compared with experimental values and those for other metals. The composition dependence of the surface tension of $\mathrm{Si}-\mathrm{C}$ alloy was then evaluated, and compared with estimates obtained using the modified Butler's model. The behavior of $\mathrm{C}$ atoms at the surface of liquid $\mathrm{Si}-\mathrm{C}$ alloys is also discussed.
\end{abstract}

KEY WORDS: molecular dynamics; surface tension of alloy; solution growth; silicon carbide.

\section{Introduction}

High-temperature solution growth using silicon-based liquid alloys as solvents is a promising method for producing high quality SiC single crystals. ${ }^{1)}$ The solution growth rate was improved by using alloy solvents with high carbon solubilities such as $\mathrm{Si}-\mathrm{Cr},{ }^{2)} \mathrm{Si}-\mathrm{Ti}^{3)}$ and $\mathrm{Fe}-\mathrm{Si}^{4)}$ alloys. These have reportedly accounted for growth rates of 100-300 $\mu \mathrm{m} / \mathrm{h}$ which are comparable to those obtained using the conventional physical vapor transport (PVT) method. Crystals grown by the solution growth method reportedly also have smaller dislocation densities ${ }^{5)}$ than those grown by PVT. Diodes fabricated from such crystals exhibit the equivalent or greater withstand voltages than those fabricated from crystals grown by PVT. ${ }^{6}$

To improve the process by growing larger diameter crystals or by increasing the growth rate, precise control of the temperature and flow in the solution is essential. Computational fluid dynamics (CFD) simulations enable the estimation of temperature and flow distributions in the solution, and are frequently employed for the process design. ${ }^{7-9)}$ However, data on the melt properties of such solvents is limited, so the properties of pure Si melt are often used instead in CFD simulations. Understanding the melt properties of Si-based alloys containing carbon is important for precisely estimating the growth conditions in various solvent systems. Especially during growth without applying forced convection in solution, the remarkable growth of $\mathrm{SiC}$ was found at the edge of the crystal/solution contact area with cylindrical

\footnotetext{
* Corresponding author: E-mail: narumi.taka.6n@kyoto-u.ac.jp DOI: https://doi.org/10.2355/isijinternational.ISIJINT-2019-308
}

liquid bridges. ${ }^{10)}$ This is presumably due to the Marangoni effect dominating the convection around the meniscus of the liquid bridge. The surface tension of the alloy solution and its temperature and composition dependence should therefore be known for controlling the Marangoni flow in the solution.

Studies on the surface tension of alloys containing carbon with the tendency to form stable metal carbides have shown varying results. Belton ${ }^{11)}$ measured the surface tension of $\mathrm{Fe}-\mathrm{Si}-\mathrm{C}$ and $\mathrm{Fe}-\mathrm{Cr}-\mathrm{C}$ alloys using a sessile drop method at a constant $\mathrm{C}$ content, and found a decrease in surface tension with increasing $\mathrm{Si}$ and $\mathrm{Cr}$ contents. This suggested a surfactive effect of the associative adsorption of $\mathrm{SiC}$ and $\mathrm{CrC}$. Kawai et al. ${ }^{12)}$ also used the sessile drop method to measure the surface tension of Fe-(1-10 mol\%) $\mathrm{Si}-(1-3 \mathrm{~mol} \%) \mathrm{C}$ alloys, and found that the maximum surface tension occurred at $2 \mathrm{~mol} \% \mathrm{Si}$ at constant $\mathrm{C}$ content. To elucidate the surfactive effect of associative $\mathrm{SiC}$ at the melt surface, one of the authors ${ }^{13)}$ measured the surface tension of $\mathrm{Fe}-(30-40 \mathrm{~mol} \%) \mathrm{Si}$ alloys using the maximum bubble pressure method. The author concluded insignificant surface segregation of $\mathrm{C}$ or associative carbide at the surface, because of little observed difference in the surface tension with and without the addition of carbon into the $\mathrm{Fe}-\mathrm{Si}$ alloy. Recently, Eustathopoulos et al. ${ }^{14)}$ reviewed the surface tension of $\mathrm{Si}$, and pointed out that $\mathrm{C}$ in the $\mathrm{Si}$ melt had no effect on the surface tension within the maximum carbon solubility. However, the behavior of $\mathrm{C}$ atoms at the melt surface has not yet been confirmed.

Molecular dynamics (MD) simulations are a useful method for investigating the behavior of atoms. Recent advances in MD have allowed the estimation of surface 
tension $^{15,16)}$ and other physical properties. ${ }^{17,18)}$ In the current study, we conducted MD simulations of stable and metastable $\mathrm{Si}-\mathrm{C}$ melts with free surfaces, to analyze the microscopic behavior of $\mathrm{Si}$ and $\mathrm{C}$ atoms at the surface and to estimate the surface tension. The surface tension of the $\mathrm{Si}-\mathrm{C}$ melts was also studied using the modified Butler's model, and the effect of carbon on the melt surface of $\mathrm{Si}$ is discussed.

\section{Simulation Method}

A classical MD simulation was performed using LAMMPS. ${ }^{19)}$ The simulation time steps were set to $0.4 \mathrm{fs}$ for Si and 0.1 fs for $\mathrm{C}$ and the Si-C alloy. A Nosé-Hoover thermostat and barostat were employed to control the temperature and pressure, respectively. ${ }^{20,21)}$ A periodic boundary was applied to all boundaries of the simulation cell. OVITO ${ }^{22)}$ was used to perform post-processing for atom visualization. According to our previous study, ${ }^{23)}$ Tersoff_94 potential ${ }^{24)}$ was used for interatomic interactions of the $\overline{\mathrm{Si}}-\mathrm{C}$ system. A total of 15552 atoms (cell volume: $18 \times 6 \times 18$ of the unit cell) of $\mathrm{Si}$ and $\mathrm{C}$ were placed in a cell with a diamond structure. The cell of the $\mathrm{Si}$ and $\mathrm{Si}-\mathrm{C}$ alloy was heated to $2600-4000 \mathrm{~K}$ and the cell of $\mathrm{C}$ was heated to 6700-7 $100 \mathrm{~K}$, and then kept at 1 atm for $100 \mathrm{ps}$ with the isobaric-isothermal ensemble to make a uniform liquid phase. Here it should be noted that the melting point of $\mathrm{Si}$ and diamond derived from Tersoff_94 potential ${ }^{24)}$ were found to be $2560 \mathrm{~K}$ and $6600 \mathrm{~K}$, respectively, in a previous study. ${ }^{23)}$ A cell of the liquid phase possessing free surfaces (vapor/liquid cell) was prepared by combining the same size of vacuum in one direction $(18 \times 18 \times 18$ of the unit cell), as shown in Fig. 1. To confirm the effect of the surface area on the simulation results, the number of $\mathrm{Si}$ atoms was varied from 768 to $27648(6 n \times 18 \times 6 n$ of the unit cell, $n=2 / 3,1,2,3,4)$. Some of $\mathrm{Si}-\mathrm{C}$ alloy employed in this study was oversaturated in comparison to the carbon solubility in the Si melt. $\left.{ }^{25}\right) \mathrm{We}$ confirmed that $\mathrm{Si}-(10-50 \mathrm{~mol} \%) \mathrm{C}$ alloy formed the uniform liquid as a

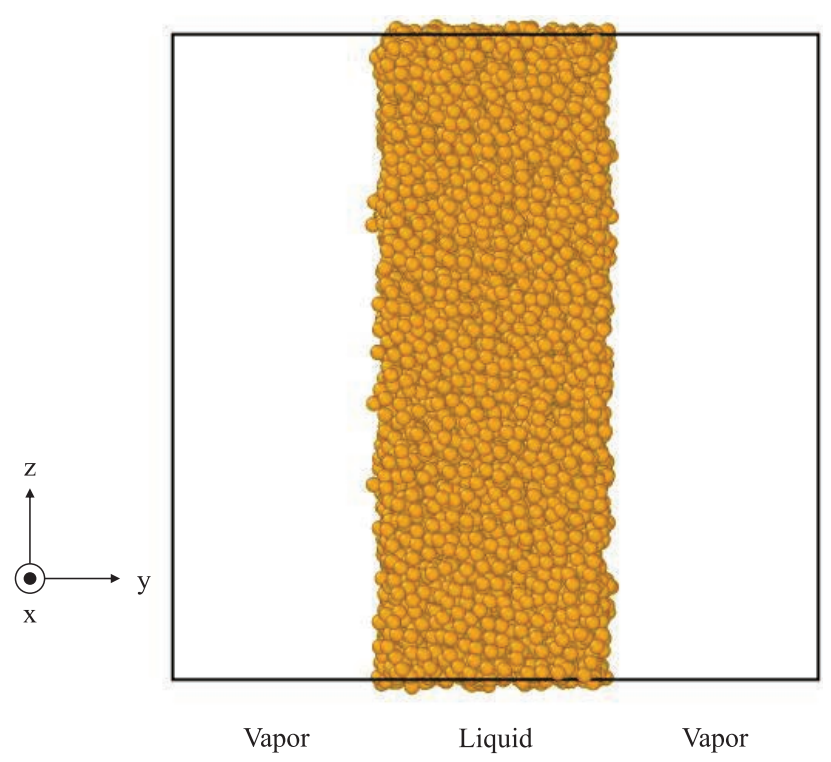

Fig. 1. Cell of Si melt including free surface (vapor/liquid cell) at $T / T_{\mathrm{m} . \mathrm{p} \text {. of Si }}=1.02$. (Online version in color.) stable or metastable phase for a calculation temperature range by the identify diamond structure (IDS) modifier ${ }^{26)}$ implemented in OVITO. The vapor/liquid cell was heated to various temperatures and kept at constant volume for 500 ps. The cells were sliced in 400 slabs for the Si melt and $\mathrm{Si}-\mathrm{C}$ alloys and in 280 slabs for the $\mathrm{C}$ melt toward the $\mathrm{y}$ axis to satisfy the thickness of the single slab smaller than the monoatomic layer thickness. The number of atoms, the number of the nearest neighbors and the potential energy in each slab were extracted to discuss the surface structure and to estimate the surface tension. The average potential energy of the bulk slabs was subtracted from the potential energy of each slab and divided by the surface area to calculate the surface tension, $\sigma$, as follows;

$$
\begin{aligned}
& \sigma=\frac{1}{A} \sum_{i=1}^{400} \Delta E_{i} \ldots \ldots \ldots \ldots . . . . . . \\
& \Delta E_{i}=E_{i}-E_{\text {Bulk }} \text { if } E_{i}<0 \\
& \Delta E_{i}=0 \text { if } E_{i} \geq 0
\end{aligned}
$$

where $A$ is the surface area of the liquid surface determined by constructing surface mesh ${ }^{22}$ implemented in OVITO; $\Delta E_{i}$ is the excess energy of the $i$ th slab; $E_{i}$ is the potential energy of the $i$ th slab; $E_{B u l k}$ is the average potential energy of the bulk liquid determined from the inflection point of the first derivative of the number density distribution of atoms. Because the melting point of $\mathrm{Si}, T_{\mathrm{m} . \mathrm{p} \text {. of Si, derived }}$ from Tersoff_94 potential $\left.{ }^{24}\right)(2560 \mathrm{~K})$ deviated from the experimental value $(1687 \mathrm{~K})$, the normalized temperature $\left(T / T_{\text {m.p. of Si }}\right)$ was used hereafter.

\section{Results and Discussion}

\subsection{Surface Tension of Si and C Melts}

Figure 2 shows the time-mean values of the number of atoms, the number of nearest neighbor atoms, the potential energy and the excess energy from Eq. (1) of a $\mathrm{Si}$ melt (15 552 atoms) at $T / T_{\text {m.p. of } \mathrm{Si}}=1.02(2600 \mathrm{~K}$ in the simulation) as an example. The duration was taken from the last 80 ps of the simulation results to obtain the time-mean values. As shown in Fig. 2(a), the number of Si atoms changed sharply near the melt surface. The thickness of the melt surface and the bulk was determined from the inflection point of the first derivative of the number density distribution of atoms. The thickness of the melt surface was about $0.25-0.30 \mathrm{~nm}$, which was comparable to 1 atomic layer because the $\mathrm{Si}-\mathrm{Si}$ bond length in the liquid phase was about $0.25 \mathrm{~nm}$ by using Tersoff_94 potential. ${ }^{24)}$ The excess energy was distributed in both free surfaces, corresponding to the distribution of the number of nearest neighbor atoms, Z. Figures 3(a) and 3(b) show the predicted radial distribution functions (RDF) of $\mathrm{Si}$ atoms and an extracted histogram of the $Z$ for the Si melt in the bulk and surface at $T / T_{\text {m.p. of } \mathrm{Si}}=1.02(2600 \mathrm{~K}$ in the simulation), respectively. The ratio of the mean $Z_{\text {Bulk }}$ to $Z_{\text {Surface }}$ obtained in this study was 0.84 , which agreed with the value proposed by Tanaka et al. ${ }^{27)}$ for general liquid metals. Figure 4 shows the correlation of the surface tension of the $\mathrm{Si}$ melt with the number of particles from 768 to 27648 at $T / T_{\text {m.p. of } \mathrm{Si}}=1.02$. The dashed lines are experimental values. ${ }^{14,28-31)}$ The estimated surface tension 

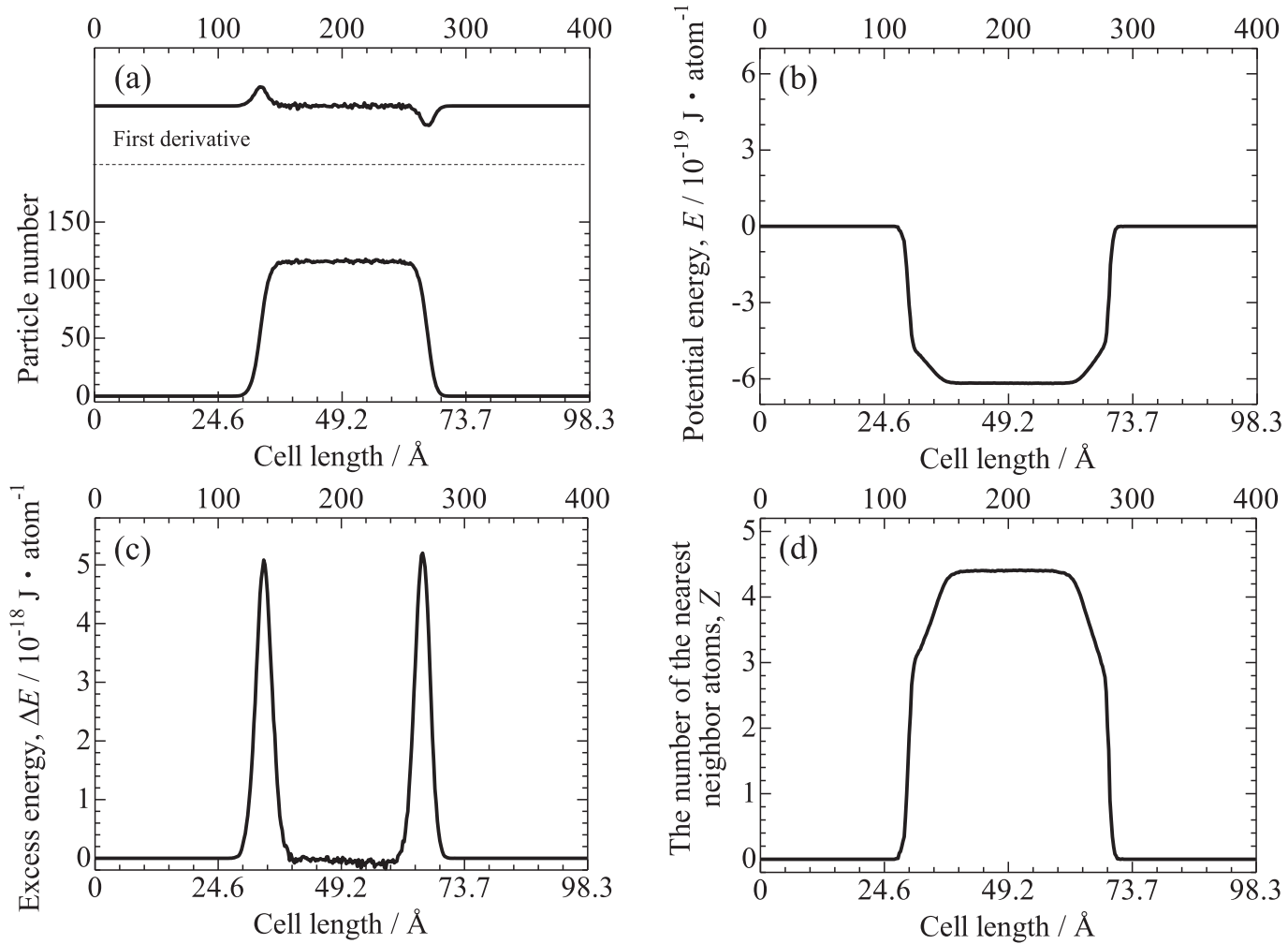

Fig. 2. Distribution of (a) the particle number and its first derivative, (b) the potential energy, (c) the excess energy and (d) the first coordination number at $T / T_{\text {m.p. of } \mathrm{Si}}=1.02$.
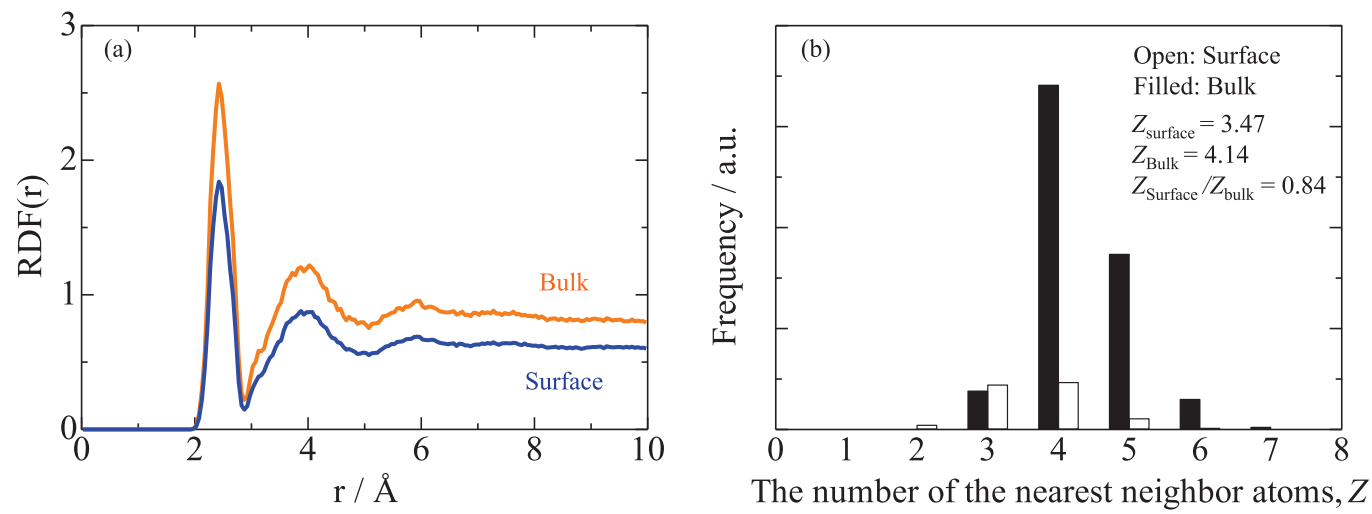

Fig. 3. (a) Radial distribution functions (RDF) of Si atoms and (b) histograms of the first coordination number of the bulk and surface for the $\mathrm{Si}$ melt at $T / T_{\mathrm{m} . \mathrm{p} \text {. of } \mathrm{Si}}=1.02$. (Online version in color.)

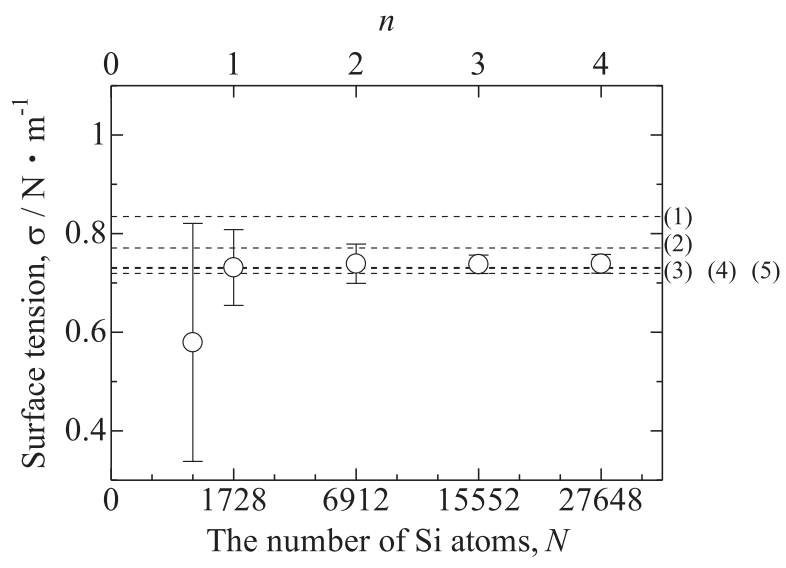

Fig. 4. Correlation of the number of Si atoms with estimated sur-

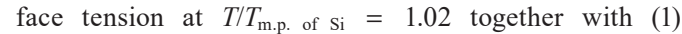
Eustathopoulos et al., ${ }^{14)}$ (2) Keene, ${ }^{28)}$ (3) Fujii et al., ${ }^{29)}$ (4) Millot et al. ${ }^{30)}$ and (5) Zhou et al. ${ }^{31)}$ increased with increasing number of $\mathrm{Si}$ atoms, and then became constant, agreeing with the reported values when the number of atoms was larger than 1728 . Therefore, we largely conducted simulations with 15552 atoms.

Figure 5 shows the surface tension of the $\mathrm{Si}$ melt as a function of temperature along with experimental values, ${ }^{14,28-31)}$ which are summarized in Table 1. Surfactive-contamination such as oxygen affects the surface tension, so several experimental values obtained by the container-less method ${ }^{29-31)}$ were chosen for comparison. The surface tension obtained in the current study agreed with data reported by Fujii et al., ${ }^{29)}$ Millot et al., ${ }^{30)}$ Zhou et $a .^{31)}$ and reviewed by Keene. ${ }^{28)}$ Although the estimated values were slightly smaller than the values suggested by Eustathopoulos et al., ${ }^{14)}$ the estimated temperature coefficient agreed with the experimental values. The densities of liquid Si and $\mathrm{C}$ are listed in Table 2 . The derived density of 
Temperature, $T / K$

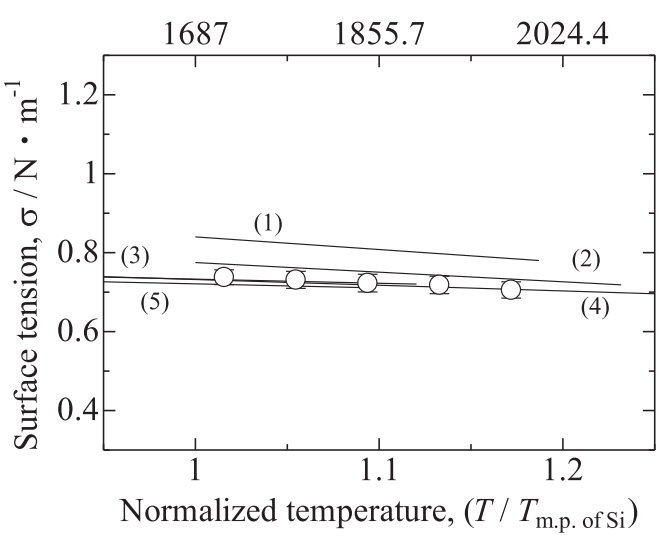

Fig. 5. Estimated surface tension of the Si melt and comparison with experimental values from (1) Eustathopoulos et al. $\left.{ }^{14}\right)$ (2) Keene, ${ }^{28)}$ (3) Fujii et al., ${ }^{29)}$ (4) Millot et al. ${ }^{30)}$ and (5) Zhou et al. ${ }^{31}$

Table 1. Estimated surface tension of the Si melt and C melt and comparison with experimental values. ${ }^{14,28-31)}$

\begin{tabular}{|c|c|c|}
\hline element & Surface tension $/ \mathrm{mN} \cdot \mathrm{m}^{-1}$ & Literature \\
\hline \multirow{6}{*}{$\mathrm{Si}$} & $742-0.0776(T-2560)$ & This study (15 552 atoms) \\
\hline & $840-0.190(T-1685)$ & Eustathopoulos et al. ${ }^{14)}$ \\
\hline & $733-0.062(T-1687)$ & Keene $^{28)}$ \\
\hline & $732-0.086(T-1685)$ & Fujii et $a{ }^{29)}$ \\
\hline & $775-0.145(T-1683)$ & Millot et al. ${ }^{30)}$ \\
\hline & $721-0.0615(T-1687)$ & Zhou et al. ${ }^{31)}$ \\
\hline $\mathrm{C}$ & $3910-0.582(T-6600)$ & This study (15 552 atoms) \\
\hline
\end{tabular}

Table 2. Estimated liquid density of the Si melt and C melt and comparison with experimental values. ${ }^{32,33)}$

\begin{tabular}{ccc}
\hline element & This study & Density $/ \mathrm{g} \cdot \mathrm{cm}^{-3}$ in literature \\
\hline Si & $\begin{array}{c}2.31-1.02 \times 10^{-4} \\
(T-2560)\end{array}$ & $2.51-2.72 \times 10^{-4}(T-1687)^{32)}$ \\
& $\begin{array}{c}2.84-4.18 \times 10^{-4} \\
\text { C }\end{array}$ & $\begin{array}{c}\text { (T-6600) } \\
\text { 3. }\end{array}$ \\
& &
\end{tabular}

liquid Si was slightly smaller than the experimental value. ${ }^{32)}$ We previously showed that the derived latent heat of fusion by MD simulation agreed fairly well with the experimental value. $^{24)}$ Figure 6 shows the proportional correlation of the surface tensions of pure metals at their melting points to their heats of evaporation derived under the assumption of $Z_{\text {Bulk }} / Z_{\text {Surface }}=0.83 .{ }^{27)}$ The surface tension of liquid $\mathrm{C}$ shows the same tendency although those of liquid Si by the present prediction and of the reported experimental value are smaller than the estimated line in spite of $Z_{\text {Bulk }} / Z_{\text {Surface }}=0.84$ as described above. We speculate that this tendency is attributed to the difference of the interatomic bonding energy of $\mathrm{Si}$ at the surface from that in the bulk although it was not clarified in the present work.

\subsection{Surface Tension of Si-C Binary System}

Figure 7 shows the time-mean values of the number of $\mathrm{Si}$ and $\mathrm{C}$ atoms for the $\mathrm{Si}-10 \mathrm{~mol} \% \mathrm{C}$ alloy at $T / T_{\text {m.p. of } \mathrm{Si}}=$

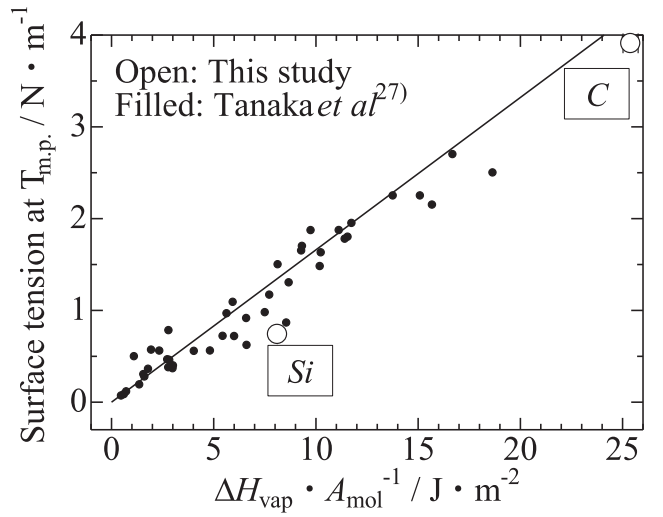

Fig. 6. Correlation of the surface tension of various metals with their latent heat of evaporation. Open circles are estimated values from the current study and black dots are values reported by Tanaka et al. ${ }^{27)}$

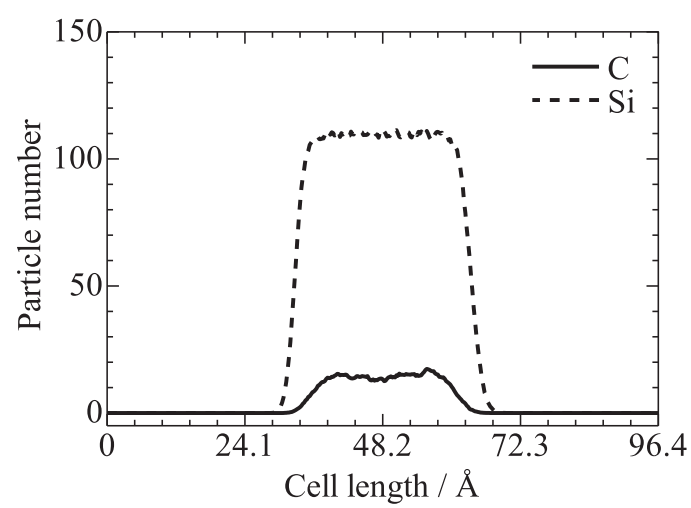

Fig. 7. Distribution of the particle number of $\mathrm{Si}$ atoms and $\mathrm{C}$ atoms at $T / T_{\mathrm{m} . \mathrm{p} \text {. of } \mathrm{Si}}=1.02$.

1.02. It was found that $\mathrm{C}$ atoms did not segregate at the melt surface. The predicted radial distribution functions (RDF) of global, $\mathrm{Si}-\mathrm{Si}, \mathrm{Si}-\mathrm{C}$, and $\mathrm{C}-\mathrm{C}$ atoms of the bulk and surface for the $\mathrm{Si}-10 \mathrm{~mol} \% \mathrm{C}$ alloy at $T / T_{\text {m.p. of } \mathrm{Si}}=1.02$ are shown in Fig. 8. The consecutive tetrahedral structure generally seen in solid $\mathrm{Si}$ or in $\mathrm{SiC}$ and any clusters did not appear in the analysis using IDS modifier. ${ }^{26)}$ Hence, it is reasonable to consider that $\mathrm{Si}$ atoms and $\mathrm{C}$ atoms placed randomly in the liquid of the MD cell. The surface tension of the $\mathrm{Si}-10 \mathrm{~mol} \% \mathrm{C}$ alloy is shown in Fig. 9 together with the evaluated values for liquid $\mathrm{Si}$ in Fig. 5 and the $\mathrm{C}$ melt. The $T / T_{\text {m.p. of Si }}$ was used for the Si melt and $\mathrm{Si}-\mathrm{C}$ alloy, whereas the $T / T_{\text {m.p. of diamond }}$ was used for liquid C. The surface tension of $\mathrm{Si}-10 \mathrm{~mol} \% \mathrm{C}$ alloy was close to that of liquid $\mathrm{Si}$. The temperature coefficient of the $\mathrm{Si}-10 \mathrm{~mol} \% \mathrm{C}$ alloy was also comparable to that of liquid $\mathrm{Si}$. The surface tension of liquid $\mathrm{C}$ was five times larger than those of the liquid $\mathrm{Si}$ and $\mathrm{Si}-10 \mathrm{~mol} \% \mathrm{C}$ alloy. This implied that it was energetically unfavorable when $\mathrm{C}$ atoms existed at the melt surface.

Figure $\mathbf{1 0}$ shows the estimated surface tensions of $\mathrm{Si}-10-50 \mathrm{~mol} \% \mathrm{C}$ alloys (15 552 atoms) compared with those of the Si melt and $\mathrm{C}$ melt at $T / T_{\text {m.p. of } \mathrm{Si}}=1.56(4000$ $\mathrm{K}$ in the simulation). Here, the extrapolated value was used because the melting point of diamond is higher than $4000 \mathrm{~K}$. Since the melting point of $\mathrm{SiC}$ was determined as $3850 \mathrm{~K}$ from a previous study, ${ }^{24)}$ we chose $4000 \mathrm{~K}$ for the comparison of the surface tension of $\mathrm{Si}-(10-50 \mathrm{~mol} \%) \mathrm{C}$. 
Although the surface tension increased with increasing $\mathrm{C}$ concentration, it was smaller than the interpolated value between the surface tension of $\mathrm{Si}$ and $\mathrm{C}$.

Here, the estimated surface tensions of $\mathrm{Si}-\mathrm{C}$ alloys were compared with estimates obtained using the modified Butler's model, ${ }^{27,34,35)}$ where the surface tension of the $\mathrm{Si}-\mathrm{C}$ binary alloy is represented by the following equations;

$$
\begin{aligned}
\sigma= & \sigma_{S i}^{\text {Pure }}+\frac{R T}{A_{S i}^{\text {mol }}} \ln \frac{1-X_{C}^{\text {Surface }}}{1-X_{C}^{\text {Bulk }}} \\
& +\frac{1}{A_{S i}^{\text {mol }}}\left\{\bar{G}_{S i}^{E x \text {, Surface }}\left(T, X_{C}^{\text {Surface }}\right)-\bar{G}_{S i}^{\text {Ex, Bulk }}\left(T, X_{C}^{\text {Bulk }}\right)\right\} \\
\sigma= & \sigma_{C}^{\text {Pure }}+\frac{R T}{A_{C}^{\text {mol }}} \ln \frac{X_{C}^{\text {Surface }}}{X_{C}^{\text {Bulk }}} \\
& +\frac{1}{A_{C}^{\text {mol }}}\left\{\bar{G}_{C}^{\text {Ex, Surface }}\left(T, X_{C}^{\text {Surface }}\right)-\bar{G}_{C}^{\text {Ex, Bulk }}\left(T, X_{C}^{\text {Bulk }}\right)\right\}
\end{aligned}
$$

where $\sigma_{i}^{\text {Pure }}$ and $A_{i}^{\text {mol }}$ are the surface tension and molar surface area of pure $i$, respectively; $X_{i}^{\text {Bulk }}$ and $X_{i}^{\text {Surface }}$ are the mole fractions of $i$ in the bulk and surface of the liquid, respectively; $\bar{G}_{i}^{\text {Ex,Bulk }}$ and $\bar{G}_{i}^{\text {Ex, Surface }}$ are the excess partial molar Gibbs energies of $i$ in the bulk and surface of the liquid, respectively. The molar surface area is given using the molar volume of $i, V_{i}^{m o l}$, and Avogadro's constant, $N_{A}$, in Eq. (4).

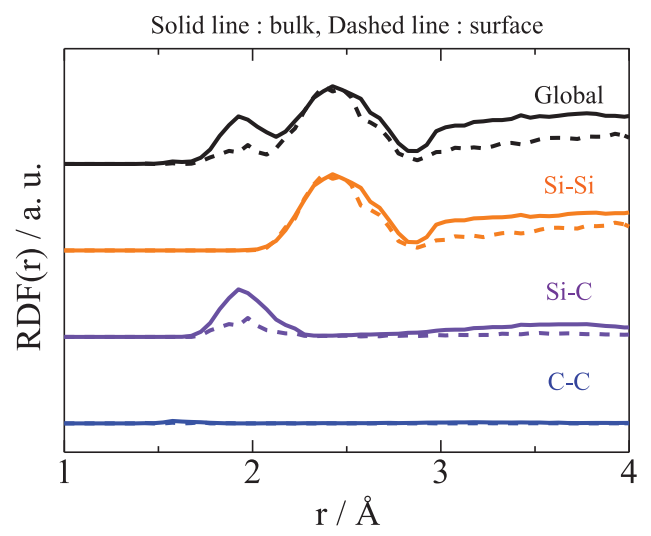

Fig. 8. Radial distribution functions (RDF) of global, $\mathrm{Si}-\mathrm{Si}, \mathrm{Si}-\mathrm{C}$ and $\mathrm{C}-\mathrm{C}$ atoms of the bulk and surface for the $\mathrm{Si}-10 \mathrm{~mol} \% \mathrm{C}$ alloy at $T / T_{\mathrm{m} . \mathrm{p} \text {. of } \mathrm{Si}}=1.02$. (Online version in color.)

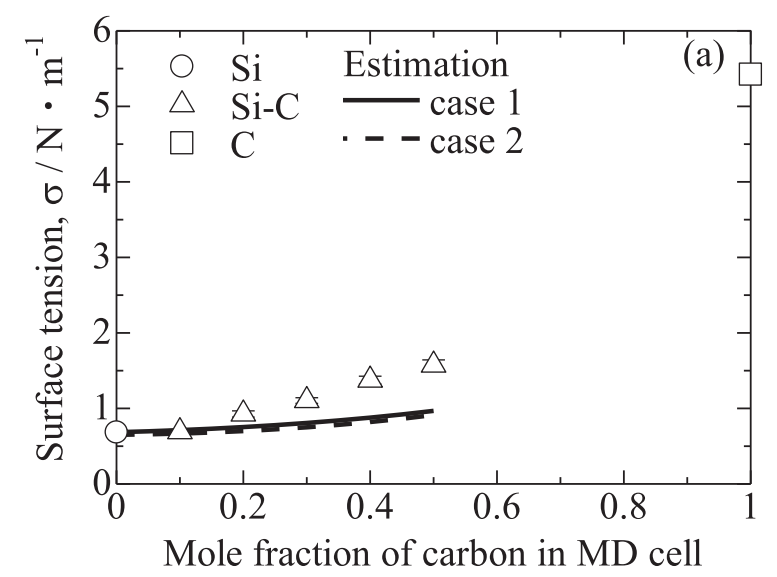

$$
A_{i}^{m o l}=1.091 N_{A}^{1 / 3}\left(V_{i}^{m o l}\right)^{2 / 3}
$$

The excess partial molar Gibbs energy in the surface monolayer was assumed as in Eq. $(5)^{27)}$

$$
\begin{aligned}
\bar{G}_{C}^{\text {Ex, Surface }}\left(T, X_{C}^{\text {Surface }}\right) & =\frac{Z^{\text {Surface }}}{Z^{\text {Bulk }}} \bar{G}_{C}^{\text {Ex, Bulk }}\left(T, X_{C}^{\text {Surface }}\right) \\
& =0.83 \bar{G}_{C}^{\text {Ex, Bulk }}\left(T, X_{C}^{\text {Surface }}\right)
\end{aligned}
$$

The estimation using the modified Butler's equation was then performed for two different cases. First, the estimation was performed for the system where both the bulk and surface phases were considered to be a mixture of Si and $\mathrm{C}$. The surface tension and the surface $\mathrm{C}$ concentration of the $\mathrm{Si}-\mathrm{C}$ alloy were estimated from Eqs. (2) and (3), and are shown as solid curves in Fig. 10. Second, the surface of the $\mathrm{Si}-\mathrm{C}$ alloy was assumed to be composed of only $\mathrm{Si}$ atoms as assumed in ref. 13, and the surface tension was estimated from Eq. (2) under the condition of $X_{c}^{\text {Surface }}=0$. This is shown as a dashed curve in Fig. 10. The difference between the two estimated curves was insignificant. As shown in Fig. 10(b), the surface $\mathrm{C}$ concentration was one order of magnitude smaller than the bulk $\mathrm{C}$ concentration in the composition region of the $\mathrm{Si}-\mathrm{C}$ alloy. A discrepancy between the surface tension of the $\mathrm{Si}-\mathrm{C}$ alloy obtained by MD simulation and the estimated values obtained by the modified Butler's model occurred when the $\mathrm{C}$ concentration of the $\mathrm{Si}-\mathrm{C}$ alloy

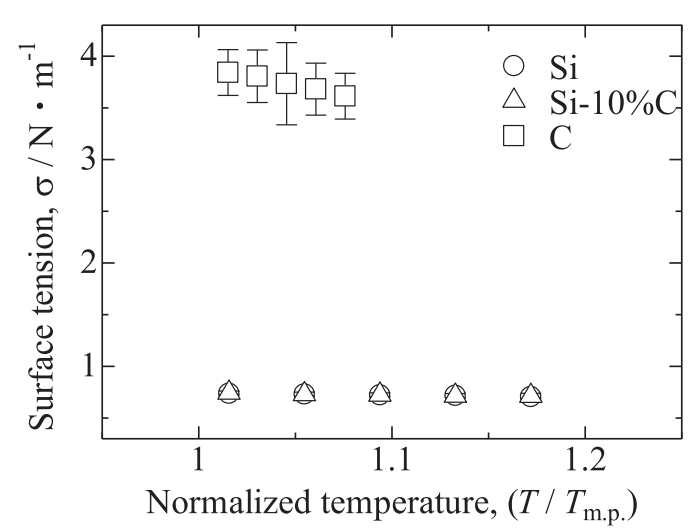

Fig. 9. Estimated surface tensions of the $\mathrm{Si}$ melt, $\mathrm{C}$ melt and $\mathrm{Si}-10 \mathrm{~mol} \% \mathrm{C}$ alloy.

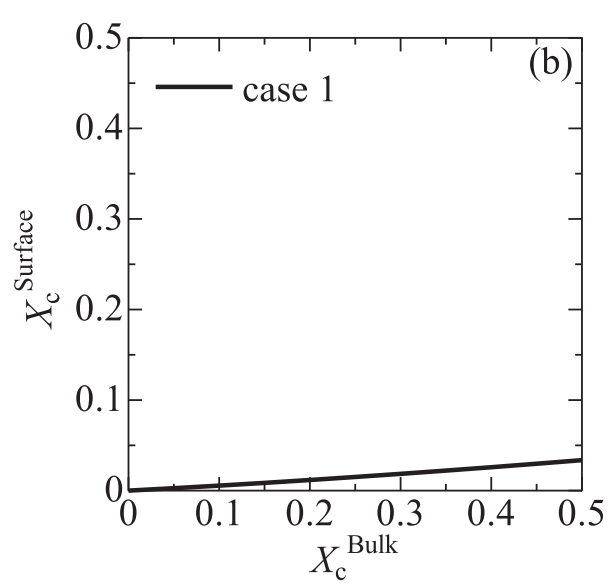

Fig. 10. (a) Correlation of the estimated surface tension of the $\mathrm{Si}-\mathrm{C}$ alloy with $\mathrm{C}$ concentration at $T / T_{\mathrm{m}}$.p. of $\mathrm{Si}=1.56$ together with the estimation obtained using the modified Butler's model. (b) Correlation of the $\mathrm{C}$ concentration at the melt surface with $\mathrm{C}$ concentration in the bulk liquid of the $\mathrm{Si}-\mathrm{C}$ alloy. 
increased. Although Tersoff_94 potential was the most suitable among reported Tersoff potentials in a previous study, ${ }^{23)}$ the heat of mixing of the $\mathrm{Si}-\mathrm{C}$ solution was different from that in ref. ${ }^{25}$ This indicated that Tersoff_94 potential was still insufficient to fully represent the $\mathrm{Si}-\mathrm{C}$ interaction. Therefore, the discrepancy became significant at large $\mathrm{C}$ concentrations, while there was minimal impact on the simulation results at small $\mathrm{C}$ concentrations. When simulation results at large $\mathrm{C}$ concentrations are required, the $\mathrm{Si}-\mathrm{C}$ interatomic potential will need to be revised.

In addition to the insignificant concentration of carbon at the surface of the Si-C alloy by MD simulation shown in Fig. 7, the modified Butler's model also negated the surface segregation of $\mathrm{C}$ in the alloy. Hence, we determined that carbon does not behave as a surfactive component at the surface of the $\mathrm{Si}-\mathrm{C}$ alloy.

\section{Conclusions}

The effect of $\mathrm{C}$ atoms on the surface tension of $\mathrm{Si}-\mathrm{C}$ alloy was investigated by MD simulations. The following conclusions were made:

(1) The derived surface tension and temperature coefficient of $\mathrm{Si}$ in this study agreed well with experimental values.

(2) The surface tension of $\mathrm{Si}-10 \mathrm{~mol} \% \mathrm{C}$ alloy was close to that of liquid $\mathrm{Si}$. From the number densities of $\mathrm{Si}$ and $\mathrm{C}$ atoms, it was found that $\mathrm{C}$ atoms did not segregate at the melt surface.

(3) The composition dependence of the derived surface tension of the $\mathrm{Si}-\mathrm{C}$ alloy was compared with estimates obtained using the modified Butler's model. The surface tension by MD simulation was consistent with the model at low $\mathrm{C}$ concentrations. The surface $\mathrm{C}$ concentration derived by MD simulation was estimated to be one order of magnitude smaller than the bulk $\mathrm{C}$ concentration. Hence, carbon did not behave as a surfactive component.

\section{Acknowledgements}

Part of this research was supported by a Grant-in-Aid for Scientific Research (B) (Grant Number 15H04166) and a Grant-in-Aid for JSPS Fellows (Grant Number 16J10300) from MEXT, Japan. We thank Aidan G. Young, PhD, from Edanz Group (www.edanzediting.com/ac) for editing a draft of this manuscript.

\section{REFERENCES}

1) D. H. Hofmann and M. H. Müller: Mater. Sci. Eng. B, 61-62 (1999), 29.

2) M. Kado, H. Daikoku, H. Sakamoto, H. Suzuki, T. Bessho, N. Yashiro, K. Kusunoki, N. Okada, K. Moriguchi and K. Kamei: Mater. Sci. Forum, 740-742 (2013), 73.

3) K. Kusunoki, K. Kamei, N. Okada, N. Yashiro, A. Yauchi, T. Ujihara and K. Nakajima: Mater. Sci. Forum, 527-529 (2006), 119.

4) T. Yoshikawa, S. Kawanishi and T. Tanaka: Jpn. J. Appl. Phys., 49 (2010), 051302.

5) K. Kamei, K. Kusunoki, N. Yashiro, N. Okada, K. Moriguchi, H. Daikoku, M. Kado, H. Suzuki, H. Sakamoto and T. Bessho: Mater. Sci. Forum, 717-720 (2012), 45.

6) K. Kusunoki, K. Seki, H. Daikoku, H. Saito, I. Kobayashi and H. Mihara: Abstract of European Conf. on Silicon Carbide and Related Materials, European Conf. on Silicon Carbide and Related Materials 2018, Birmingham, (2018), INV.P.02.

7) F. Mercier, J. M. Dedulle, D. Chaussende and M. Pons: J. Cryst. Growth, 213 (2010), 155.

8) T. Yamamoto, N. Adkar, Y. Okano, T. Ujihara and S. Dost: J. Cryst. Growth, 474 (2017), 50.

9) K. Ariyawong, Y. J. Shin, J. M. Dedulle and D. Chaussende: Cryst. Growth Des., 16 (2016), 3231.

10) S. Kawanishi, T. Yoshikawa, K. Morita, N. Okada, K. Kusunoki and K. Kamei: J. Cryst. Growth, 381 (2013), 121.

11) G. Belton: Metall. Trans., 3 (1972), 1465.

12) Y. Kawai, K. Mori, M. Kishimoto, K. Ishikura and T. Shimada: Tetsu-to-Hagané, 60 (1974), 29 (in Japanese).

13) T. Yoshikawa: Mater. Trans., 54 (2013), 1968

14) N. Eustathopoulos and B. Drevet: J. Cryst. Growth, 371 (2013), 77.

15) M. J. P. Nijmeijer, A. F. Bakker, C. Bruin and J. H. Sikkenk: J. Chem. Phys., 89 (1988), 3789.

16) H. Daiguji and E. Hihara: Heat Mass Transf., 35 (1999), 213.

17) F. Müller-Plathe: J. Chem. Phys., 106 (1998), 6082.

18) F. Müller-Plathe: Phys. Rev. E, 59 (1999), 4894.

19) S. Plimpton: J. Comput. Phys., 117 (1995), 1.

20) S. Nosé: J. Chem. Phys., 81 (1984), 511.

21) W. G. Hoover: Phys. Rev. A, 31 (1985), 1695

22) A. Stukowski: Modell. Simul. Mater. Sci. Eng., 18 (2010), 015012.

23) T. Narumi, Y. Shibuta and T. Yoshikawa: J. Cryst. Growth, 494 (2018), 36.

24) J. Tersoff: Phys. Rev. B, 49 (1994), 16349.

25) S. Kawanishi, T. Yoshikawa and T. Tanaka: Mater. Trans., 50 (2009), 806

26) E. Maras, O. Trushin, A. Stukowski, T. Ala-Nissila and H. Jonsson: Comput. Phys. Commun., 205 (2016), 13.

27) T. Tanaka, K. Hack, T. Iida and S. Hara: Z. Metallkd., 87 (1996), 380.

28) B. J. Keene: Int. Mater. Rev., 38 (1993), 157.

29) H. Fujii, T. Matsumoto, S. Izutani, S. Kiguchi and K. Nogi: Acta Mater., 54 (2006), 1221

30) F. Millot, V. Sarou-Kanian, J. C. Rifflet and B. Vinet: Mater. Sci. Eng. A, 495 (2008), 8.

31) Z. Zhou, S. Mukherjee and W. K. Rhim: J. Cryst. Growth, 257 (2003), 350.

32) Y. Inatomi, F. Onishi, K. Nagashio and K. Kuribayashi: Int. J. Thermophys., 28 (2007), 44.

33) A. I. Savvatimskiy: Carbon, 43 (2005), 1115.

34) J. A. V. Butler: Proc. R. Soc. A, 135 (1932), 348.

$35)$ K. S. Yeum, R. Speiser and D. R. Poirier: Metall. Trans. B, 20 (1989), 693. 